\title{
The Role of Apolipoprotein E in Guillain-Barré Syndrome and Experimental Autoimmune Neuritis
}

\author{
Hong-liang Zhang, ${ }^{1,2}$ Jiang $\mathrm{Wu}^{1}$ and Jie $\mathrm{Zhu}^{1,2}$ \\ ${ }^{1}$ Department of Neurology, The First Hospital of Jilin University, 130021, Changchun, China \\ ${ }^{2}$ Department of Neurobiology, Care Sciences and Society, Karolinska Institute, Karolinska University Hospital Huddinge, \\ SE-141 86, Stockholm, Sweden
}

Correspondence should be addressed to Jiang Wu, sjnkwujiang@vip.sina.com and Jie Zhu, jie.zhu@ki.se

Received 12 October 2009; Accepted 20 December 2009

Academic Editor: Don Mark Estes

Copyright ( $\odot 2010$ Hong-liang Zhang et al. This is an open access article distributed under the Creative Commons Attribution License, which permits unrestricted use, distribution, and reproduction in any medium, provided the original work is properly cited.

Apolipoprotein E (apoE) is a $34.2 \mathrm{kDa}$ glycosylated protein characterized by its wide tissue distribution and multiple functions. ApoE has been widely studied in lipid metabolism, cardiocerebrovascular diseases, and neurodegenerative diseases like Alzheimer's disease and mild cognitive impairment, and so forth. Recently, a growing body of evidence has pointed to nonlipid related properties of apoE, including suppression of $\mathrm{T}$ cell proliferation, regulation of macrophage function, facilitation of lipid antigen presentation by CD1 molecules to natural killer T (NKT) cells, and modulation of inflammation and oxidation. By these properties, apoE impacts physiology and pathophysiology at multiple levels. The present paper summarizes updated studies on the immunoregulatory function of apoE, with special focus on isoform-specific effects of apoE on Guillain-Barré syndrome (GBS) and its animal model experimental autoimmune neuritis (EAN).

\section{Introduction}

Apolipoprotein E (ApoE) is a $34.2 \mathrm{kDa}$ glycosylated protein with 299 amino acid residues. The APOE gene is located on chromosome 19q13.2, consisting of four exons and three introns and spanning 3597 nucleotides [1]. There are three isoforms in human (apoE2, apoE3, and apoE4) due to different amino acid residues at positions 112 and 158, among which apoE3, with a cysteine residue at position 112 and an arginine residue at position 158, is the most common. The other two "variants," apoE2 and apoE4, respectively, contain two arginines and two cysteines at positions 112 and 158 [2]. However, there is only one isoform of apoE in rodents, which resembles human apoE3 in terms of lipoprotein binding and metabolism, preferably associating with high density lipoprotein (HDL), the clearance of which is mediated principally by hepatic low density lipoprotein receptors (LDLRs) [3, 4].

ApoE is synthesized predominantly in the liver, but also by cells in the spleen, brain, lung, kidney, ovary, adrenal, and muscle tissues. Hepatic parenchyma cells are the main apoE producing cells in mammalian body, probably accounting for two thirds to three fourths of the plasma apoE [5]. In the nervous system, apoE mRNA is present in neurons, astrocytes, ependymal cells, nonmyelinating Schwann cells, but not in microglia, oligodendroglia, choroidal cells, or myelinating Schwann cells [6-8]. As reported by a variety of studies, apoE produced by mammalian cells exists in different forms, monomers, dimers, modified, unmodified, lipid-rich, and lipid-poor, and so forth [9-13]. It is noteworthy that there is limited permeability of the blood brain barrier (BBB) to apoE, and local synthesis and production by brain tissue contribute to the homeostasis of apoE in brain tissue and cerebrospinal fluid (CSF) [14].

ApoE has been widely studied in lipid metabolism, cardiocerebrovascular diseases [15], multiple sclerosis (MS) $[16,17]$, neurodegenerative diseases such as Alzheimer's disease $[18,19]$, and mild cognitive impairment $[20,21]$. In addition, growing evidence points to nonlipid-related properties of apoE. An immunoregulatory role of apoE has been proposed for decades. This role was originally described as suppression of lymphocyte activation [22-25]. Only in 
the recent years, with the development of $A P O E$ knockout mice and APOE transgenic ( $\mathrm{Tg}$ ) mice, have the studies on the specific mechanism of immunomodulation been greatly deepened. In this paper, we outlined the immunoregulatory functions of apoE, with exclusive focus on the isoformspecific effects of apoE on Guillain-Barré syndrome (GBS) and its animal model experimental autoimmune neuritis (EAN).

\section{The Role of ApoE in Immune Responses}

To date, there has been strong evidence supporting a role for apoE as an immunomodulatory agent in immune responses. Effects of apoE on immune system are extensive and some of them are dependent on different ligands of the protein, different concentrations, and lipid-binding state. The properties include suppression of $\mathrm{T}$ cell proliferation [26], stimulation of cultured neutrophils [27], regulation of macrophage functions [28-32], facilitation of lipid antigen presentation by CD1 molecules to natural killer $\mathrm{T}$ (NKT) cells $[33,34]$, and modulation of inflammation and oxidation $[35,36]$, and so forth. By these properties, apoE impacts physiology and pathophysiology at multiple levels.

This role of apoE was originally discovered as an immunoinhibitory activity of plasma lipoproteins in vitro by a variety of experiments [23,37-44]. Succedent studies ascribed this activity to immunoregulatory functions of apoE. A series of studies demonstrated both apoE containing lipoproteins and multimers of synthetic apoE peptides inhibited proliferation of cultured lymphocytes by inhibiting DNA synthesis and reducing phospholipid turnover in T cells [26, 45-48]. APOE knockout mice greatly facilitate apoE research. ApoE-deficient mice showed abnormal humoral and cellular immune responses. Significantly higher levels of antigenspecific IgM and significantly decreased antigen-specific delayed-type hypersensitivity responses were shown in apoEdeficient mice after immunization with tetanus toxoid as compared with control C57BL/6 mice [49]. Moreover, spleen weights of apoE-deficient animals were greater than ageand sex-matched C57BL/6 controls, indicating an idiopathic immune dysfunction in apoE-deficient mice [49]. In vivo, apoE downregulates $\mathrm{T}$ helper (Th) 1 immune responses, which is postulated to be mediated by either modification of macrophage or $\mathrm{T}$ cell functions [50, 51]. ApoE can also affect innate and acquired immune responses in vitro by its ability to suppress stimulation of cultured neutrophils [27]. Hypercholesterolaemia resulting from $A P O E$ knockout, can facilitate Th2 immune responses in mice [52], indicating that apoE plays a double-role in immune responses.

ApoE can bind lipopolysaccharide (LPS), attenuate the inflammatory response, and thus reduce LPS induced lethality [53]. Injection of LPS stimulated higher expression of inflammatory cytokines like tumor necrosis factor- $\alpha$ (TNF$\alpha$ ), interleukin (IL)- $1 \beta$, IL- 12 , and interferon- $\gamma$ (IFN- $\gamma$ ), as well as IL-6, and so forth, in the brains of apoE-deficient mice compared with wild type controls $[49,50,54]$. And apoEdeficient mice have impaired immune responses to bacterial challenge with Listeria monocytogenes, and increased susceptibility to endotoxemia after intravenous LPS injection $[55,56]$. Moreover, these mice are highly susceptible to tuberculosis, which has been suggested to depend upon the severity of hypercholesterolemia [57], and Klebsiella pneumoniae infection [58]. The deficiency of neutralization of Gram negative LPS seems to be one of the reasons that may explain this susceptibility. As regards isoform-specific effects that may exist, $A P O E \varepsilon 2 \mathrm{Tg}$ mice appear to be more susceptible to endotoxin or bacterial infection [59]. Ophir et al. have shown that either intraperitoneal or intraventricular injection of LPS results in significantly higher production of proinflammatory cytokines, defense response genes or chemotaxis genes in APOE $\varepsilon 3 \mathrm{Tg}$ mice than in APOE $\varepsilon 4 \mathrm{Tg}$ ones [60].

In the immune system, apoE is primarily produced by macrophages, which act as principal effector cells in both innate and adaptive immunity [61-63]. It is observed that pretreatment with apoE reduces inflammatory signaling in astrocytes and microglia in the brain [35, 64-67], and classical activation of macrophages by proinflammatory stimuli such as IFN- $\gamma$, TNF- $\alpha$, IL- $1 \beta$ and LPS, downregulates apoE production [68-73]. However, transforming growth factor- $\beta$ and estrogen promote apoE synthesis and release [73-76]. ApoE suppresses proinflammatory signaling in macrophages, and vice versa, indicating an intricate apoEmediated feedback regulation of inflammation and immune responses.

The production of nitric oxide (NO) represents one of the principle features of activated macrophages, and NO is considered to be a principal effector of macrophagemediated immune responses. In mononuclear-phagocyte system, NO is formed enzymatically from L-arginine by inducible NO synthase (iNOS), which yields L-citrulline as a coproduct [77]. Treatment of microglia and peripheral macrophages with apoE could increase NO production stimulated by IFN- $\gamma$, and LPS, and so forth [78]. This effect supports its potential role in innate immune responses [29, 79]. ApoE alone is unable to induce the production of either iNOS mRNA or protein. Its action results from alteration of arginine availability by apoE [80]. Interestingly, the effect of apoE on NO production is not found only in macrophages. NO production in platelets can be stimulated likewise by apoE [81]. Further studies demonstrated that microglia and peripheral macrophages from male APOE $\varepsilon 4 \mathrm{Tg}$ mice could produce significantly higher levels of NO than from APOE E3 $\mathrm{Tg}$ mice. This increase in nitrite production reflects an increase in the innate immune response of the APOE $\varepsilon 4$ $\mathrm{Tg}$ macrophages $[30,32]$. Similar results were found also in human studies [82]. The increased NO production was shown to be coupled with an increased arginine uptake in male APOE \&4 Tg mice and to depend on p38 mitogen activited protein kinase (MAPK) $[83,84]$; whereas it is not the case in female mice. Macrophages from female $A P O E$ $\mathrm{Tg}$ mice produced higher level of NO than male ones, and there is no isoform-dependent difference as in male ones $[30,85,86]$.

Activation of macrophages and microglia is important in both the innate immunity and adaptive immunity [87, 88]. ApoE can down-regulate microglial activation [89]. 
Duan et al. in our group found that apoE deficiency enhances activation of microglia in CNS and aggravates kainic acid (KA) induced hippocampal neurodegeneration. Increased CC chemokine receptor 3 expression on microglia in apoE-deficient mice after KA administration appeared to facilitate the microglial recruitment and accumulation in the injured areas [90]. Macrophages of apoE-deficient mice stimulated by exogenous antigen are more effective in the upregulating of main histocompatibility complex (MHC) class II molecules and costimulatory molecules like CD40 and CD80, with increased IFN- $\gamma$ secretion in responding T cells [91]. Furthermore, apoE suppressed the secretion of TNF- $\alpha$ and IL-1 $\beta$ in an isoform-specific fashion (E2 > E3 > E4) [84]. A significantly higher level of TNF- $\alpha$ was observed in the supernatant of cultured macrophages derived from adult male APOE $\varepsilon 4 \mathrm{Tg}$ mice compared with macrophages from $A P O E \& 3$ ones [28]. ApoE genotype significantly affects the cellular immune response in stably transfected murine macrophages. In apoE4 versus apoE3 macrophages, higher levels of proinflammatory cytokines including TNF- $\alpha$ appeared evident followed by LPS stimulation [92]. ApoE displayed an isoform-specific effect on inflammation in primary adult microglia, with apoE4 potent to stimulate production of prostaglandin E2 and IL-1 $\beta$ [93]. APOE $\varepsilon 4$ targeted replacement (TR) mice demonstrate a proinflammatory phenotype including increased iNOS mRNA synthesis and NO production, and higher proinflammatory cytokine production (TNF- $\alpha$, IL-6, IL-12p40) in glial cell culture, compared with $A P O E \varepsilon 3$ TR mice [28]. Activation of primary astrocytes from $A P O E$ TR mice with LPS led to genotype-dependent differences in cytokine secretion that were the greatest in APOE $\varepsilon 2$ TR mice [94]. Taken together, these findings suggest immunomodulatory dysfunction in apoE 4 isoform. Similar to apoE-deficient mice, APOE $\varepsilon 4$ $\mathrm{Tg}$ mice seem to bear an insufficiency to deal with an inflammatory insult.

Although the antigen presenting function of antigen presenting cells (APCs) in adaptive immunity appears to increase in apoE-deficient mice, there still lacks direct evidence that apoE functions directly on antigen presentation process. The difference might either be due to the increased susceptibility to proinflammatory stimulation, resulting in the high expression of MHC class II molecules and costimulatory molecules on innate immune cells like macrophages, or be due to tendency to Th1 cytokine production in apoEdeficient mice. However, a role of apoE in facilitating lipid antigen presentation by CD1 molecules to NKT cells has been presented and confirmed, which appears of great importance in autoimmune diseases $[95,96]$. Naïve NKT cells express high level surface marker NK1.1 and an invariant T cell receptor (TCR) [34, 97-100]. Upon TCR ligation, they respond rapidly to secrete high levels of IFN- $\gamma$ and IL4 , which has been postulated to be of great importance in the shaping of adaptive immune responses and the shifting between Th1 and Th2 immune responses [101-103] (Figure 1). CD 1 molecules (CD1a-d in humans and CD1d in mice), similar in structure to MHC molecules, resemble MHC II molecules in function in that they present lipid antigens to NKT cells, in which process, apoE is implicated.

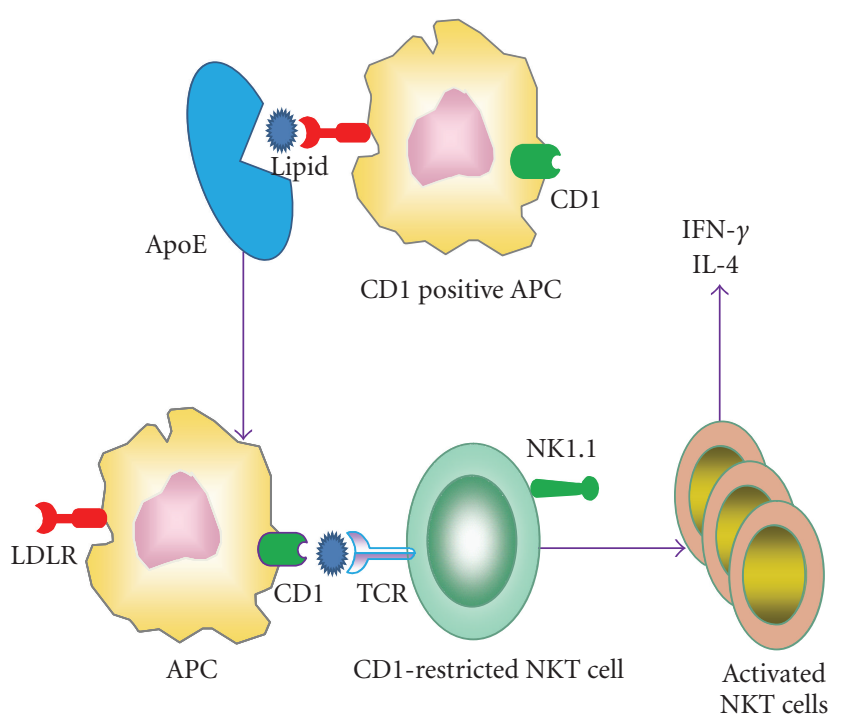

Schematic illustration of apoE-facilitated

CD1-restricted NKT cell activation process

FIgURe 1: ApoE facilitates activation of CD1 restricted NKT cells. Inactivated NKT cells express surface marker of NK1.1 and an invariant TCR. ApoE facilitates lipid antigen presentation by CD1 positive APCs mainly through binding to LDLR. And then CD1 molecules present lipid antigen to NKT cells. Upon TCR ligation, naive NKT cells respond rapidly to secrete high levels of IFN- $\gamma$ and IL-4.

ApoE, the major serum factor that binds lipids, could efficiently bind lipid antigens and dramatically facilitate their presentation by CD1b, CD1c and CD1d molecules via the binding to LDLR $[33,104]$. More recently, human $\mathrm{B}$ cells have been demonstrated to utilize apoE-mediated pathways of lipid antigen presentation more efficiently than dendritic cells [105]. In terms of CD1-mediated selflipid presentation, apoE might be involved in autoimmune diseases due to facilitation of self-lipid antigen presentation by CD1 molecules to NKT cells. ApoE might provide a pathway for the delivery of self-antigens and subsequently contribute to inflammatory diseases like MS [31, 106-109]. Kattan et al. suggested that apoE treatment also promoted a Th1 cytokine response in a rat model of sepsis. Whether this is partly due to facilitation of CD1 restricted lipid antigen presented by apoE remains to be clarified [110], and whether this effect of apoE is isotype-dependent is not yet known.

In vitro, apoE can inhibit proliferation of antigen and mitogen stimulated CD4+ and CD8+ T cells, which although not precisely known, has been suggested to be mediated by modification of IL-2 receptor or modification of intracellular signaling pathways perhaps involving calcium and phosphatidylinositol [111-113], while there seems no isoformdependent suppression on $\mathrm{T}$ cell proliferation stimulated by phytohemagglutinin, or anti-CD3, as revealed by an in vitro human study [49]. Of note is that apoE is naturally presented by murine MHC II molecules. In a pathophysiological state this might be of immunological significance $[114,115]$. And a naturally processed self-peptide from 
apolipoprotein E, Ep1.B, is capable of inducing dendritic cell differentiation. Nuclear factor $\kappa \mathrm{B}(\mathrm{NF} \kappa \mathrm{B})$, a transcription factor essential for DC differentiation, is fundamental in mediating the effects. [116]. A peptide containing the receptor binding region (residues 133-149), other than apoE holoprotein, is enough to suppress inflammation [117]. This peptide is almost the same as the one proposed by Pham et al. to be responsible for antioxidant properties [118]. In addition, apoE deficiency results in elevated autoimmune activity in mice, which can be detected as early as 7 weeks of age, and might explain the susceptibility of deficient mice to either EAN or EAE [119]. Moreover, apoE deficiency in mice leads to impaired clearance of apoptotic cells and a systemic proinflammatory condition, independent of its role in lipoprotein metabolism [120], providing another possible mechanism by which apoE may influence immune responses and autoimmune diseases.

The exact molecular mechanisms by which apoE isoforms alter the immune responses still remain undefined. However they have been postulated to influence different signaling pathways. ApoE isoforms might be in part responsible for the differential modulation of the redox sensitive transcription pathways such as $\mathrm{NF} \kappa \mathrm{B}$ and MAPK $[36,86$, 94]. Alternatively, apoE can act by binding to cell surface receptors. LDLR-related protein (LRP) is postulated to be implicated to mediate the immunomodulatory effects of apoE, albeit there is no difference in the binding affinity of apoE isotypes with LRP $[121,122]$.

\section{The Role of ApoE in GBS and EAN}

GBS is presently defined as an organ specific immune mediated disorder resulting from a synergistic interaction between cellular and humoral immune responses to incompletely characterized antigens in the peripheral nervous system (PNS) $[123,124]$. As yet, there has been no evidence that $A P O E$ genotype may influence susceptibility to GBS or its clinical course [125]. It might be either due to the small sample size of the experiment or due to the difference of $A P O E$ allele distribution and GBS clinical features among populations.

In several studies attempting to find specific biomarker of GBS in the serum and CSF, apoE was shown to decrease in CSF in GBS patients. Our group used comparative proteomic methods to show a decreased level of apoE in CSF, which was later confirmed by other researchers [126, 127]. This was further confirmed by enzyme-linked immunosorbent assay in our group (unpublished data). As there is limited permeability of the BBB to lipoproteins [14, 128, 129], this change might be due to a decrease of local apoE synthesis and secretion by brain tissue, as part of systemic decrease of apoE synthesis in acute phage reaction [4].

The blood nerve barrier (BNB) breakdown and autoreactive $\mathrm{T}$ cell penetrating $\mathrm{BNB}$ are crucial in the initiation of GBS [130, 131]. Data from animal experiments suggested that BNB dysfunction resulting from apoE deficiency might lead to more susceptibility to GBS, and exacerbate clinical GBS [132, 133]. Although there still lacks evidence that
apoE isoforms contribute differently in maintaining BNB or $\mathrm{BBB}$ integrity, considering the preference of apoE isoforms binding to different lipoprotein and apoE receptors, it might be presumed that apoE isoforms might influence the recovery of GBS due to cholesterol transport difference in regeneration and remyelination $[134,135]$.

EAN, first described in rabbits in 1955 by Waksman and Adams [136], is a CD4+ T cell mediated autoimmune disease of PNS, characterized by perivascular infiltration of $\mathrm{T}$ cells and macrophages, and demyelination in the peripheral nerves in pathological feature, which can be induced in susceptible animal strains including mouse, rat, sheep, chicken, and monkey by active immunization with peripheral nerve myelin [136] or its component P0 or P2 proteins or their neuritogenic peptides $[137,138]$ together with complete Freud's adjuvant. EAN shares many of clinical, immunological, electrophysiological, and morphological characteristics with GBS, thus serves as a useful model for exploring the pathogenesis and immunotherapy of GBS. ApoE can modulate immune responses in EAN through modification of functions of macrophages, $\mathrm{T}$ cells, and BNB, shifting Th1/Th2 balance, as well as other effects (Figure 2). Autoreactive T cells penetrating the broken-down $\mathrm{BNB}$ to accumulate in peripheral nervous tissue gives rise to the effector phase of the immune response in EAN [139]. A number of observations support the role of apoE in maintaining the integrity of the $\mathrm{BNB}$ or $\mathrm{BBB}$. And apoEdeficient mice were shown to suffer impaired BNB and BBB, which might be one of the reasons why apoE-deficient mice underwent more severe EAN $[132,133]$. ApoE may inhibit the migration of blood derived inflammatory cells across the BNB or the transduction of chemotactic signals for migration. This is a critical step in the migratory process of inflammatory cells across tight endothelial junctions [140, 141].

Previously, we explored the role of apoE in P0 peptide 180-199 induced EAN. Our data, in accordance with data from other studies, showed that apoE deficiency increased antigen presentation capacity of macrophages, which can explain the elevated susceptibility to EAN in apoE-deficient mice $[91,133]$. We further revealed an increased susceptibility to EAN after upregulation of the autoreactive T cell response to peripheral nerve components in $A P O E$ knockout mice. The results provided strong evidence that apoE might act as an inhibitor for EAN by inhibiting the Th1 response and $\mathrm{P} 0$-specific antibody production. Shifting the Th1/Th2 to the Th1 direction is one mechanism underlying increased susceptibility to EAN in apoEdeficient mice. Th cells can differentiate to Th1 and Th2 subpopulations with cross-regulating cytokine profiles that may play a decisive role in the initiation and termination of an autoimmune process [142]. Dysregulation of the Th1/Th2 balance can result in autoimmune diseases [143]. In EAN, Th1 cytokines predominate and mediate inflammatory damage, whereas Th2 cytokines are associated with recovery from the disease [144-147]. ApoE-deficient mice were shown to produce higher levels of IFN- $\gamma$, IL-12, and TNF- $\alpha$ and lower levels of IL-10 than C57BL/6 mice in EAN. 


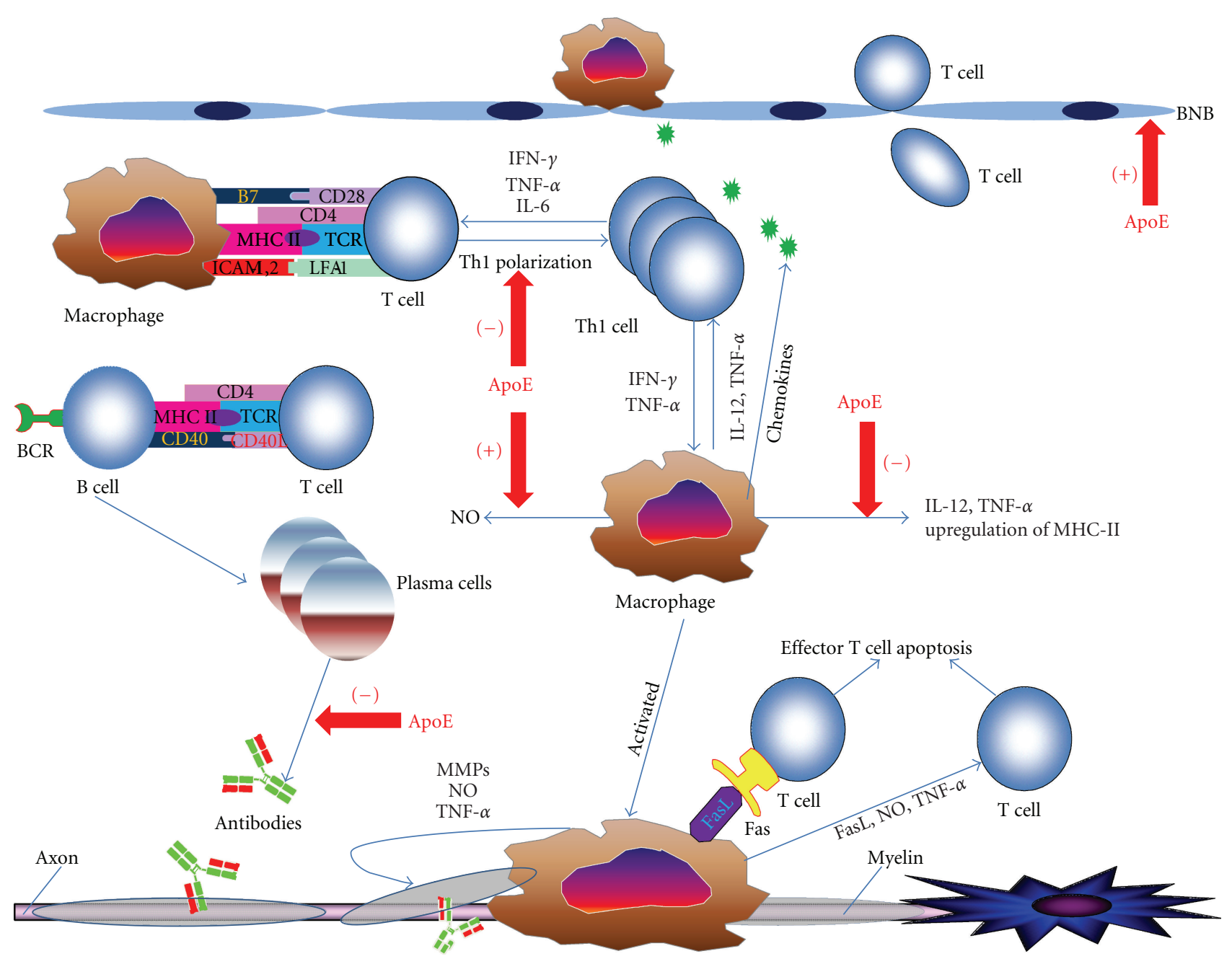

Potential roles of apoE in the pathogenesis of EAN

FIGURE 2: Schematic illustration of the potential role of apoE in the pathogenesis of EAN. ApoE can modulate immune responses in EAN through modification of functions of macrophages, T cells, and BNB, and through shifting Th1/Th2 balance. (-) suppressive function; (+) supportive function.

Macrophages are the principal antigen presenting cells and effector cells in the pathogenesis of EAN. In demyelinated peripheral nerves, the MHC class II positive cells are mainly macrophages [148]. The pivotal role of macrophages in immune-mediated nerve damage is direct phagocytic attack on myelin, and the release of proinflammatory cytokines including TNF- $\alpha$, IL- 1 ; and IL- 6 and other noxious molecules $[149,150]$. A variety of studies demonstrated an isoform-specific effect of apoE on macrophage functions, including NO production and cytokine secretion $[28,30,79]$. Considering the critical importance of $\mathrm{NO}$ and cytokines in the pathogenesis of EAN, this effect might contribute to isoform-dependent susceptibility or clinical severity of EAN $[151,152]$. Schwann cells can function as facultative antigen presenting cells in certain conditions (see review by Meyer zu Hörste et al.) [153]. Duan et al. in our group, further revealed that the antigen presenting capacity of Schwann cells in apoE-deficient mice was enhanced, which might occur via down-regulation of intracellular IL-6 production. SCs may actively participate in local immune resonses as a source of IL-6 in the PNS [154]. ApoE-deficient mice were observed to reduce the expression of intracellular IL- 6 accompanied with higher levels of MHC II and CD 40 expression on SCs. Moreover, an enhanced antigen-presenting function of SCs was found in apoE-deficient mice to P0 peptide 180-199 specific $T$ cells [155].

Ongoing studies in our group have shown a preliminary result of an isotype-specific effect of apoE in EAN, with the most severe clinical course occurring on APOE $\varepsilon 4$ $\mathrm{Tg}$ mice, while with the least severe EAN on APOE $\varepsilon 3$ Tg mice (unpublished data). Apart from all above, strong evidence supports a crucial role of apoE in peripheral nerve regeneration and remyelination [156]. ApoE has been proposed to scavenge lipid debris from the degenerating myelin and provide it to sprouting axons via LDLR-mediated endocytosis [157, 158]. Despite this, regenerating nerves in 
both apoE-deficient and control mice were morphologically indistinguishable one month after sciatic nerve crush [159], indicating a surrogate effect of other apolipoproteins in PNS regeneration.

\section{Conclusions and Prospective}

The immunomodulatory functions of apoE have been extensively studied in the past decades. Increasing studies have focused on the ambiguous or even controversial isotype-dependent effects. It appears difficult partly due to the difficulty of interpretation of results from animal experiments to a general conclusion. For example, the difference of serum and tissue apoE concentration in APOE $\varepsilon 2, \varepsilon 3$, and $\varepsilon 4 \mathrm{Tg}$ mice might be a confounding factor when comparing the isotype-dependent effects of apoE on immune system and immune responses [28, 160-163]. Domain interaction, which distinguishes apoE4 from apoE2 and apoE3 in biological function, has been suggested to contribute to the detrimental effects of apoE4 [163, 164]. Because of domain interaction, apoE4 bind preferentially to very low density lipoproteins, which are more rapidly removed from plasma than other lipoproteins such as HDL, to which apoE3 and apoE2 binds preferentially [164-166]. Also of note is that apoE levels in the CNS vary during the estrous cycle and estrogen could increase ApoE levels [76, 167-169]. Moreover, the lipid-free apoE was shown only to bind LRP $[93,170,171]$. Therefore in interpreting the effects of apoE on immune responses, its lipidation state, its concentration, and its location of action must be taken into consideration. It still remains to be defined whether a crucial, isoform-dependent activity of apoE role exists in GBS, or MS, considering the different distribution of $A P O E$ allele in the whole population. Anyhow, preliminary findings about the role of apoE in immune system and immune responses have shed light on the research of autoimmune diseases such as GBS and MS. The elucidation of the exact mechanisms by which apoE functions on immunity is appealing in that it may provide new insight to preventive or therapeutic strategies of autoimmune diseases and even other diseases [172].

\section{Acknowledgments}

The work was supported by grants from China Scholarship Council, Swedish Medicine Association, Swedish National Board of Health and Welfare, as well as funds from Karolinska Institute.

\section{References}

[1] S. C. Rall Jr., K. H. Weisgraber, and R. W. Mahley, "Human apolipoprotein E. The complete amino acid sequence," The Journal of Biological Chemistry, vol. 257, pp. 4171-4178, 1982.

[2] K. H. Weisgraber, "Apolipoprotein E: structure-function relationships," Advances in Protein Chemistry, vol. 45, pp. 249-302, 1994.
[3] R. L. Raffai, L. M. Dong, R. V. Farese Jr., and K. H. Weisgraber, "Introduction of human apolipoprotein E4 "domain interaction" into mouse apolipoprotein E," Proceedings of the National Academy of Sciences of the United States of America, vol. 98, pp. 11587-11591, 2001.

[4] L. Li, P. A. Thompson, and R. L. Kitchens, "Infection induces a positive acute phase apolipoprotein E response from a negative acute phase gene: role of hepatic LDL receptors," Journal of Lipid Research, vol. 49, no. 8, pp. 1782-1793, 2008.

[5] R. W. Mahley, "Apolipoprotein E: cholesterol transport protein with expanding role in cell biology," Science, vol. 240, no. 4852, pp. 622-630, 1988.

[6] J. K. Boyles, R. E. Pitas, E. Wilson, R. W. Mahley, and J. M. Taylor, "Apolipoprotein E associated with astrocytic glia of the central nervous system and with nonmyelinating glia of the peripheral nervous system," Journal of Clinical Investigation, vol. 76, no. 4, pp. 1501-1513, 1985.

[7] U. Beffert, M. Danik, P. Krzywkowski, C. Ramassamy, F. Berrada, and J. Poirier, "The neurobiology of apolipoproteins and their receptors in the CNS and Alzheimer's disease," Brain Research Reviews, vol. 27, no. 2, pp. 119-142, 1998.

[8] L. M. Refolo and H. M. Fillit, "Apolipoprotein E4 as a target for developing new therapeutics for Alzheimer's disease," Journal of Molecular Neuroscience, vol. 23, no. 3, pp. 151-155, 2004.

[9] V. I. Zannis, D. M. Kurnit, and J. L. Breslow, "Hepatic apoA-I and Apo-E and intestinal Apo-A-I are synthesized in precursor isoprotein forms by organ cultures of human fetal tissues," Journal of Biological Chemistry, vol. 257, no. 1, pp. 536-544, 1982.

[10] V. I. Zannis, J. M. Ordovas, C. Cladaras, F. S. Cole, G. Forbes, and E. J. Schaefer, "mRNA and apolipoprotein E synthesis abnormalities in peripheral blood monocyte macrophages in familial apolipoprotein E deficiency," Journal of Biological Chemistry, vol. 260, no. 24, pp. 12891-12894, 1985.

[11] V. I. Zannis, J. van der Spek, and D. Silverman, "Intracellular modifications of human apolipoprotein E," Journal of Biological Chemistry, vol. 261, pp. 13415-13421, 1986.

[12] M. Mahmood Hussain, E. E. Zanni, M. Kelly, and V. I. Zannis, "Synthesis, modification, and flotation properties of rat hepatocyte apolipoproteins," Biochimica et Biophysica Acta, vol. 101, no. 1, pp. 90-101, 1989.

[13] S. Aleshkov, C. R. Abraham, and V. I. Zannis, "Interaction of nascent apoe2, apoe3, and apoe4 isoforms expressed in mammalian cells with amyloid peptide $\beta(1-40)$. Relevance to Alzheimer's disease," Biochemistry, vol. 36, no. 34, pp. 10571-10580, 1997.

[14] R. W. Mahley, K. H. Weisgraber, and Y. Huang, "Apolipoprotein E: structure determines function, from atherosclerosis to Alzheimer's disease to AIDS," Journal of Lipid Research, vol. 50, pp. S183-S188, 2009.

[15] D. S. Knopman, R. O. Roberts, Y. E. Geda, et al., "Association of prior stroke with cognitive function and cognitive impairment: a population-based study," Archives of Neurology, vol. 66, no. 5, pp. 614-619, 2009.

[16] L. J. Julian, L. Vella, D. Frankel, S. L. Minden, J. R. Oksenberg, and D. C. Mohr, "ApoE alleles, depression and positive affect in multiple sclerosis," Multiple Sclerosis, vol. 15, no. 3, pp. 311-315, 2009.

[17] A. A. Mazurek and J. Shi, "APOE epsilon4 allele is associated with cognitive impairment in patients with multiple sclerosis," Neurology, vol. 71, p. 1203, 2008. 
[18] J. Kim, J. M. Basak, and D. M. Holtzman, "The role of apolipoprotein E in Alzheimer's disease," Neuron, vol. 63, no. 3, pp. 287-303, 2009.

[19] Z. Guo, L. Fratiglioni, M. Viitanen, et al., "Apolipoprotein E genotypes and the incidence of Alzheimer's disease among persons aged 75 years and older: variation by use of antihypertensive medication?" American Journal of Epidemiology, vol. 153, pp. 225-231, 2001.

[20] M. Ewers, Z. Zhong, K. Bürger, et al., "Increased CSF-BACE 1 activity is associated with ApoE- $\varepsilon 4$ genotype in subjects with mild cognitive impairment and Alzheimer's disease," Brain, vol. 131, no. 5, pp. 1252-1258, 2008.

[21] R. Heun, U. Gühne, T. Luck, et al., "Apolipoprotein E allele 4 is not a sufficient or a necessary predictor of the development of mild cognitive impairment," European Psychiatry, vol. 25, no. 1, pp. 15-18, 2010.

[22] M. Clay, G. Anantharamaiah, M. Mistry, A. Balasubramaniam, and J. Harmony, "Localization of a domain in apolipoprotein E with both cytostatic and cytotoxic activity," Biochemistry, vol. 34, no. 35, pp. 11142-11151, 1995.

[23] M. Macy, Y. Okano, A. Cardin, E. Avila, and J. Harmony, "Suppression of lymphocyte activation by plasma lipoproteins," Cancer Research, vol. 43, supplement 5, pp. 2496s2502s, 1983.

[24] M. Mistry, M. Clay, M. Kelly, M. Steiner, and J. Harmony, "Apolipoprotein E restricts interleukin-dependent T lymphocyte proliferation at the G1(A)/G1(B) boundary," Cellular Immunology, vol. 160, no. 1, pp. 14-23, 1995.

[25] M. Pepe and L. Curtiss, "Apolipoprotein E is a biologically active constituent of the normal immunoregulatory lipoprotein, LDL-In," Journal of Immunology, vol. 136, no. 10, pp. 3716-3723, 1986.

[26] E. M. Avila, G. Holdsworth, N. Sasaki, R. L. Jackson, and J. A. Harmony, "Apoprotein E suppresses phytohemagglutininactivated phospholipid turnover in peripheral blood mononuclear cells," Journal of Biological Chemistry, vol. 257, no. 10, pp. 5900-5909, 1982.

[27] R. A. Terkeltaub, G. A. Dyer, J. Martin, and L. K. Curtiss, "Apolipoprotein (Apo) E inhibits the capacity of monosodium urate crystals to stimulate neutrophils characterization of intraarticular Apo E and demonstration of Apo E binding to urate crystals in vivo," Journal of Clinical Investigation, vol. 87, no. 1, pp. 20-26, 1991.

[28] M. P. Vitek, C. M. Brown, and C. A. Colton, "APOE genotype-specific differences in the innate immune response," Neurobiology of Aging, vol. 30, no. 9, pp. 1350-1360, 2009.

[29] S. W. Barger and A. D. Harmon, "Microglial activation by alzhelmer amyloid precursor protein and modulation by apolipoprotein E," Nature, vol. 388, no. 6645, pp. 878-881, 1997.

[30] C. Brown, E. Wright, C. Colton, P. Sullivan, D. Laskowitz, and M. Vitek, "Apolipoprotein E isoform mediated regulation of nitric oxide release," Free Radical Biology and Medicine, vol. 32, no. 11, pp. 1071-1075, 2002.

[31] C. Colton, C. Brown, M. Czapiga, and M. Vitek, "Apolipoprotein-E allele-specific regulation of nitric oxide production," Annals of the New York Academy of Sciences, vol. 962, pp. 212-225, 2002.

[32] C. A. Colton, C. Brown, D. Cook, et al., "APOE and the regulation of microglial nitric oxide production: a link between genetic risk and oxidative stress," Neurobiology of Aging, vol. 23, no. 5, pp. 777-785, 2002.
[33] P. van den Elzen, S. Garg, L. Leon, et al., "Apolipoproteinmediated pathways of lipid antigen presentation," Nature, vol. 437, p. 906, 2005.

[34] N. A. Borg, K. S. Wun, L. Kjer-Nielsen, et al., "CD1dlipid-antigen recognition by the semi-invariant NKT T-cell receptor," Nature, vol. 448, no. 7149, pp. 44-49, 2007.

[35] J. R. Lynch, D. Morgan, J. Mance, W. Matthew, and D. Laskowitz, "Apolipoprotein E modulates glial activation and the endogenous central nervous system inflammatory response," Journal of Neuroimmunology, vol. 114, no. 1-2, pp. 107-113, 2001.

[36] G. Ophir, N. Amariglio, J. Jacob-Hirsch, R. Elkon, G. Rechavi, and D. M. Michaelson, "Apolipoprotein E4 enhances brain inflammation by modulation of the NF- $\kappa \mathrm{B}$ signaling cascade," Neurobiology of Disease, vol. 20, no. 3, pp. 709-718, 2005.

[37] K. Schumacher, G. Maerker Alzer, and U. Wehmer, "A lymphocyte inhibiting factor isolated from normal human liver," Nature, vol. 251, no. 5476, pp. 655-656, 1974.

[38] J. H. Morse, L. D. Witte, and D. S. Goodman, "Inhibition of lymphocyte proliferation stimulated by lectins and allogeneic cells by normal plasma lipoproteins," Journal of Experimental Medicine, vol. 146, no. 6, pp. 1791-1803, 1977.

[39] F. V. Chisari, "Immunoregulatory properties of human plasma in very low density lipoproteins," Journal of Immunology, vol. 119, no. 6, pp. 2129-2136, 1977.

[40] D. Y. Hui and J. A. Harmony, "Phosphatidylinositol turnover in mitogen-activated lymphocytes. Suppression by lowdensity lipoproteins," Biochemical Journal, vol. 192, no. 1, pp. 91-98, 1980.

[41] D. Y. Hui and J. A. Harmony, "Inhibition by low density lipoproteins of mitogen-stimulated cyclic nucleotide production by lymphocytes," Journal of Biological Chemistry, vol. 255, no. 4, pp. 1413-1419, 1980.

[42] L. K. Curtiss and T. S. Edgington, "The biologic activity of the immunoregulatory lipoprotein, LDL-in, is independent of its free fatty acid content," Journal of Immunology, vol. 126, no. 4, pp. 1382-1386, 1981.

[43] J. A. Cuthbert and P. E. Lipsky, "Immunoregulation by low density lipoproteins in man. Inhibition of mitogen-induced $\mathrm{T}$ lymphocyte proliferation by interference with transferrin metabolism," Journal of Clinical Investigation, vol. 73, no. 4, pp. 992-1003, 1984.

[44] A. L. Akeson, D. W. Scupham, and J. A. Harmony, "The phosphatidylinositol response and proliferation of oxidative enzyme-activated human T lymphocytes: suppression by plasma lipoproteins," Journal of Lipid Research, vol. 25, no. 11, pp. 1195-1205, 1984.

[45] D. Hui, J. Harmony, T. Innerarity, and R. Mahley, "Immunoregulatory plasma lipoproteins. Role of apoprotein E and apoprotein B," Journal of Biological Chemistry, vol. 255, no. 24, pp. 11775-11781, 1980.

[46] M. G. Pepe and L. K. Curtiss, "Apolipoprotein E is a biologically active constituent of the normal immunoregulatory lipoprotein, LDL-In," Journal of Immunology, vol. 136, no. 10, pp. 3716-3723, 1986.

[47] C. A. Dyer, R. S. Smith, and L. K. Curtiss, "Only multimers of a synthetic peptide of human apolipoprotein E are biologically active," Journal of Biological Chemistry, vol. 266, no. 23, pp. 15009-15015, 1991.

[48] M. J. Mistry, M. A. Clay, M. E. Kelly, M. A. Steiner, and J. A. Harmony, "Apolipoprotein E restricts interleukin-dependent T lymphocyte proliferation at the G1A/G1B boundary," Cell Immunology, vol. 160, pp. 14-23, 1995. 
[49] D. T. Laskowitz, D. M. Lee, D. Schmechel, and H. F. Staats, "Altered immune responses in apolipoprotein E-deficient mice," Journal of Lipid Research, vol. 41, no. 4, pp. 613-620, 2000.

[50] E. Laurat, B. Poirier, E. Tupin, et al., "In vivo downregulation of $\mathrm{T}$ helper cell 1 immune responses reduces atherogenesis in apolipoprotein E-knockout mice," Circulation, vol. 104, no. 2, pp. 197-202, 2001.

[51] K. Ali, M. Middleton, E. Puré, and D. J. Rader, "Apolipoprotein E suppresses the type I inflammatory response in vivo," Circulation Research, vol. 97, no. 9, pp. 922-927, 2005.

[52] A. K. Robertson, X. Zhou, B. Strandvik, and G. K. Hansson, "Severe hypercholesterolaemia leads to strong Th2 responses to an exogenous antigen," Scandinavian Journal of Immunology, vol. 59, no. 3, pp. 285-293, 2004.

[53] M. Van Oosten, P. C. Rensen, E. S. Van Amersfoort, et al., "Apolipoprotein E protects against bacterial lipopolysaccharide-induced lethality: a new therapeutic approach to treat gram-negative sepsis," The Journal of Biological Chemistry, vol. 276, pp. 8820-8824, 2001.

[54] P. Davenport and P. G. Tipping, "The role of interleukin4 and interleukin-12 in the progression of atherosclerosis in apolipoprotein E-deficient mice," American Journal of Pathology, vol. 163, no. 3, pp. 1117-1125, 2003.

[55] N. de Bont, M. G. Netea, N. N. Demacker, et al., "Apolipoprotein E knock-out mice are highly susceptible to endotoxemia and Klebsiella pneumoniae infection," Journal of Lipid Research, vol. 40, pp. 680-685, 1999.

[56] S. E. Roselaar and A. Daugherty, "Apolipoprotein E-deficient mice have impaired innate immune responses to Listeria monocytogenes in vivo," Journal of Lipid Research, vol. 39, no. 9, pp. 1740-1743, 1998.

[57] G. W. Martens, M. C. Arikan, J. Lee, F. Ren, T. Vallerskog, and H. Kornfeld, "Hypercholesterolemia impairs immunity to tuberculosis," Infection and Immunity, vol. 76, no. 8, pp. 3464-3472, 2008.

[58] N. de Bont, M. G. Netea, P. N. Demacker, B. J. Kullberg, J. W. van der Meer, and A. F. Stalenhoef, "Apolipoprotein Edeficient mice have an impaired immune response to Klebsiella pneumoniae," European Journal of Clinical Investigation, vol. 30, pp. 818-822, 2000.

[59] L. Jofre-Monseny, A. M. Minihane, and G. Rimbach, "Impact of apoE genotype on oxidative stress, inflammation and disease risk," Molecular Nutrition and Food Research, vol. 52, no. 1, pp. 131-145, 2008.

[60] G. Ophir, N. Amariglio, J. Jacob-Hirsch, R. Elkon, G. Rechavi, and D. M. Michaelson, "Apolipoprotein E4 enhances brain inflammation by modulation of the NF- $\kappa \mathrm{B}$ signaling cascade," Neurobiology of Disease, vol. 20, no. 3, pp. 709-718, 2005.

[61] S. K. Basu, M. S. Brown, Y. K. Ho, R. J. Havel, and J. L. Goldstein, "Mouse macrophages synthesize and secrete a protein resembling apolipoprotein E," Proceedings of the National Academy of Sciences of the United States of America, vol. 78, pp. 7545-7549, 1981.

[62] S. K. Basu, J. L. Goldstein, and M. S. Brown, "Independent pathways for secretion of cholesterol and apolipoprotein E by macrophages," Science, vol. 219, no. 4586, pp. 871-873, 1983.

[63] R. Takemura and Z. Werb, "Modulation of apoprotein E secretion in response to receptor-mediated endocytosis in resident and inflammatory macrophages," Journal of Experimental Medicine, vol. 159, no. 1, pp. 167-178, 1984.
[64] F. Baskin, G. M. Smith, J. A. Fosmire, and R. N. Rosenberg, "Altered apolipoprotein E secretion in cytokine treated human astrocyte cultures," Journal of the Neurological Sciences, vol. 148, no. 1, pp. 15-18, 1997.

[65] D. T. Laskowitz, S. Goel, E. R. Bennett, and W. D. Matthew, "Apolipoprotein E suppresses glial cell secretion of TNF $\alpha$," Journal of Neuroimmunology, vol. 76, no. 1-2, pp. 70-74, 1997.

[66] D. T. Laskowitz, A. D. Thekdi, S. D. Thekdi, et al., "Downregulation of microglial activation by apolipoprotein $\mathrm{E}$ and apoE-mimetic peptides," Experimental Neurology, vol. 167, no. 1, pp. 74-85, 2001.

[67] R. Aleong, J. F. Blain, and J. Poirier, "Pro-inflammatory cytokines modulate glial apolipoprotein E secretion," Current Alzheimer Research, vol. 5, no. 1, pp. 33-37, 2008.

[68] K. Brand, N. Mackman, and L. K. Curtiss, "Interferon- $\gamma$ inhibits macrophage apolipoprotein E production by posttranslational mechanisms," Journal of Clinical Investigation, vol. 91, no. 5, pp. 2031-2039, 1993.

[69] R. Oropeza, H. Wekerle, and Z. Werb, "Expression of apolipoprotein E by mouse brain astrocytes and its modulation by interferon- $\gamma$," Brain Research, vol. 410, no. 1, pp. 45-51, 1987.

[70] J. Saura, V. Petegnief, X. Wu, Y. Liang, and S. Paul, "Microglial apolipoprotein $\mathrm{E}$ and astroglial apolipoprotein J expression in vitro: opposite effects of lipopolysaccharide," Journal of Neurochemistry, vol. 85, no. 6, pp. 1455-1467, 2003.

[71] M. Starck, P. Bertrand, S. Pepin, F. Schiele, G. Siest, and M. M. Galteau, "Effects of pro-inflammatory cytokines on apolipoprotein E secretion by a human astrocytoma cell line (CCF-STTG1)," Cell Biochemistry and Function, vol. 18, no. 1, pp. 9-16, 2000.

[72] Z. Werb and J. Chin, "Apoprotein E is synthesized and secreted by resident and thioglycollate-elicited macrophages but not by pyran copolymer- or bacillus Calmette-Guerinactivated macrophages," Journal of Experimental Medicine, vol. 158, no. 4, pp. 1272-1293, 1983.

[73] S. Zuckerman, G. Evans, and L. O’Neal, “Cytokine regulation of macrophage apo E secretion: opposing effects of GM-CSF and TGFb," Atherosclerosis, vol. 96, no. 2-3, pp. 203-214, 1992.

[74] J. Levin-Allerhand, B. S. McEwen, C. Lominska, D. Lubahn, K. Korach, and J. Smith, "Brain region-specific up-regulation of mouse apolipoprotein E by pharmacological estrogen treatments," Journal of Neurochemistry, vol. 79, no. 4, pp. 796-803, 2001.

[75] R. Srivastava, N. Srivastava, M. Averna, et al., "Estrogen up-regulates apolipoprotein E (ApoE) gene expression by increasing ApoE mRNA in the translating pool via the estrogen receptor $\alpha$-mediated pathway," Journal of Biological Chemistry, vol. 272, no. 52, pp. 33360-33366, 1997.

[76] D. Stone, I. Rozovsky, T. Morgan, C. Anderson, H. Hajian, and C. Finch, "Astrocytes and microglia respond to estrogen with increased apoE mRNA in vivo and in vitro," Experimental Neurology, vol. 143, no. 2, pp. 313-318, 1997.

[77] D. J. Stuehr, H. J. Cho, N. S. Kwon, M. F. Weise, and C. F. Nathan, "Purification and characterization of the cytokineinduced macrophage nitric oxide synthase: An FAD- and FMN-containing flavoprotein," Proceedings of the National Academy of Sciences of the United States of America, vol. 88, no. 17, pp. 7773-7777, 1991.

[78] M. Vitek, J. Snell, O. Chernyshev, and C. Colton, "Modulation of nitric oxide production in human macrophages by apolipoprotein-E and amyloid-beta peptide," Biochemical 
and Biophysical Research Communications, vol. 240, no. 2, pp. 391-394, 1997.

[79] R. Egensperger, S. Kösel, U. Von Eitzen, and M. B. Graeber, "Microglial activation in Alzheimer disease: association with APOE genotype," Brain Pathology, vol. 8, no. 3, pp. 439-447, 1998.

[80] C. A. Colton, M. Czapiga, J. Snell-Callanan, O. N. Chernyshev, and M. P. Vitek, "Apolipoprotein E acts to increase nitric oxide production in macrophages by stimulating arginine transport," Biochimica et Biophysica Acta, vol. 1535, no. 2, pp. 134-144, 2001.

[81] D. Riddell, "Apolipoprotein E inhibits platelet aggregration through the l-arginine: nitric oxide pathway," The Journal of Biological Chemistry, vol. 272, pp. 89-95, 1997.

[82] C. A. Colton, L. K. Needham, C. Brown, et al., "APOE genotype-specific differences in human and mouse macrophage nitric oxide production," Journal of Neuroimmunology, vol. 147, no. 1-2, pp. 62-67, 2004.

[83] M. Czapiga and C. A. Colton, "Microglial function in human APOE3 and APOE4 transgenic mice: altered arginine transport," Journal of Neuroimmunology, vol. 134, no. 1-2, pp. 44-51, 2003.

[84] I. Maezawa, M. Nivison, K. S. Montine, N. Maeda, and T. J. Montine, "Neurotoxicity from innate immune response is greatest with targeted replacement of E4 allele of apolipoprotein E gene and is mediated by microglial p38MAPK," FASEB Journal, vol. 20, no. 6, pp. 797-799, 2006.

[85] C. Brown, Q. Xu, N. Okhubo, M. Vitek, and C. A. Colton, "Androgen-mediated immune function is altered by the apolipoprotein E gene," Endocrinology, vol. 148, no. 7, pp. 3383-3390, 2007.

[86] C. M. Brown, E. Choi, Q. Xu, M. Vitek, and C. A. Colton, "The APOE4 genotype alters the response of microglia and macrophages to $17 \beta$-estradiol," Neurobiology of Aging, vol. 29, no. 12, pp. 1783-1794, 2008.

[87] S. Gordon, "Alternative activation of macrophages," Nature Reviews Immunology, vol. 3, no. 1, pp. 23-35, 2003.

[88] S. Lehnardt, L. Massillon, P. Follett, et al., "Activation of innate immunity in the CNS triggers neurodegeneration through a Toll-like receptor 4-dependent pathway," Proceedings of the National Academy of Sciences of the United States of America, vol. 100, no. 14, pp. 8514-8519, 2003.

[89] D. T. Laskowitz, W. D. Matthew, E. R. Bennett, et al., "Endogenous apolipoprotein E suppresses LPS-stimulated microglial nitric oxide production," Neuro Report, vol. 9, no. 4, pp. 615-618, 1998.

[90] R. S. Duan, Z. Chen, Y. C. Dou, et al., "Apolipoprotein E deficiency increased microglial activation/CCR3 expression and hippocampal damage in kainic acid exposed mice," Experimental Neurology, vol. 202, no. 2, pp. 373-380, 2006.

[91] C. Tenger and X. Zhou, "Apolipoprotein E modulates immune activation by acting on the antigen-presenting cell," Immunology, vol. 109, no. 3, pp. 392-397, 2003.

[92] L. Jofre-Monseny, A. Loboda, A. E. Wagner, et al., "Effects of apoE genotype on macrophage inflammation and heme oxygenase-1 expression," Biochemical and Biophysical Research Communications, vol. 357, no. 1, pp. 319-324, 2007.

[93] S. Chen, N. T. Averett, A. Manelli, M. J. Ladu, W. May, and M. D. Ard, "Isoform-specific effects of apolipoprotein E on secretion of inflammatory mediators in adult rat microglia," Journal of Alzheimer's Disease, vol. 7, no. 1, pp. 25-35, 2005.
[94] I. Maezawa, N. Maeda, T. J. Montine, and K. S. Montine, "Apolipoprotein E-specific innate immune response in astrocytes from targeted replacement mice," Journal of Neuroinflammation, vol. 3, article 10, 2006.

[95] D. Chaussabel, R. T. Semnani, M. A. McDowell, D. Sacks, A. Sher, and T. B. Nutman, "Unique gene expression profiles of human macrophages and dendritic cells to phylogenetically distinct parasites," Blood, vol. 102, no. 2, pp. 672-681, 2003.

[96] F. Le Naour, L. Hohenkirk, A. Grolleau, et al., "Profiling changes in gene expression during differentiation and maturation of monocyte-derived dendritic cells using both oligonucleotide microarrays and proteomics," Journal of Biological Chemistry, vol. 276, no. 21, pp. 17920-17931, 2001.

[97] A. Bendelac, M. N. Rivera, S. H. Park, and J. H. Roark, "Mouse CD1-specific NK1 T cells: development, specificity, and function," Annual Review of Immunology, vol. 15, pp. 535-562, 1997.

[98] S. Cardell, S. Tangri, S. Chan, M. Kronenberg, C. Benoist, and D. Mathis, "CD1-restricted $\mathrm{CD} 4+\mathrm{T}$ cells in major histocompatibility complex class II- deficient mice," Journal of Experimental Medicine, vol. 182, no. 4, pp. 993-1004, 1995.

[99] S. M. Behar, T. A. Podrebarac, C. J. Roy, C. R. Wang, and M. B. Brenner, "Diverse TCRs recognize murine CD1," Journal of Immunology, vol. 162, article 161, 1999.

[100] L. Brossay, S. Tangri, M. Bix, S. Cardell, R. Locksley, and M. Kronenberg, "Mouse CD1-autoreactive T cells have diverse patterns of reactivity to CD1+ targets," Journal of Immunology, vol. 160, no. 8, pp. 3681-3688, 1998.

[101] H. Chen and W. E. Paul, "Cultured NK1.1+CD4+ T cells produce large amounts of IL- 4 and IFN- $\gamma$ upon activation by anti-CD3 or CD1," Journal of Immunology, vol. 159, p. 2240, 1997.

[102] T. Yoshimoto, A. Bendelac, C. Watson, J. Hu-Li, and W. E. Paul, "Role of NK1.1+ T cells in a TH2 response and in immunoglobulin E production," Science, vol. 270, no. 5243, pp. 1845-1847, 1995.

[103] A. K. Singh, M. T. Wilson, S. Hong, et al., "Natural killer T cell activation protects mice against experimental autoimmune encephalomyelitis," Journal of Experimental Medicine, vol. 194, no. 12, pp. 1801-1811, 2001.

[104] M. Brigl and M. B. Brenner, "CD1: antigen presentation and T cell function,” Annual Review of Immunology, vol. 22, pp. 817-890, 2004.

[105] L. L. Allan, K. Hoefl, D. J. Zheng, et al., “Apolipoprotein mediated lipid antigen presentation in B cells provides a pathway for innate help by NKT cells," Blood, vol. 114, no. 12, pp. 2411-2416, 2009.

[106] E. Tupin, A. Nicoletti, R. Elhage, et al., "CD1d-dependent activation of NKT cells aggravates atherosclerosis," Journal of Experimental Medicine, vol. 199, no. 3, pp. 417-422, 2004.

[107] R. W. Mahley and S. C. Rall Jr., "Apolipoprotein E: far more than a lipid transport protein," Annual Review of Genomics and Human Genetics, vol. 1, pp. 507-537, 2000.

[108] F. Fazekas, S. Strasser-Fuchs, H. Kollegger, et al., "Apolipoprotein E epsilon 4 is associated with rapid progression of multiple sclerosis," Neurology, vol. 57, pp. 853-857, 2001.

[109] A. Shamshiev, A. Donda, I. Carena, et al., "Self glycolipids as T-cell autoantigens," European Journal of Immunology, vol. 29, no. 5, pp. 1667-1675, 1999.

[110] O. M. Kattan, F. B. Kasravi, E. L. Elford, M. T. Schell, and H. W. Harris, "Apolipoprotein E-mediated immune regulation in sepsis," Journal of Immunology, vol. 181, no. 2, pp. 13991408, 2008. 
[111] M. E. Kelly, M. A. Clay, M. J. Mistry, L. H. Hsieh, and J. A. Harmony, "Apolipoprotein E inhibition of proliferation of mitogen-activated T lymphocytes: production of interleukin 2 with reduced biological activity," Cellular Immunology, vol. 159, no. 2, pp. 124-139, 1994.

[112] L. Bocksch, T. Stephens, A. Lucas, and B. Singh, "Apolipoprotein E: possible therapeutic target for atherosclerosis," Current Drug Targets-Cardiovascular \& Haematological Disorders, vol. 1, no. 2, pp. 93-106, 2001.

[113] G. S. Getz and C. A. Reardon, "Apoprotein E as a lipid transport and signaling protein in the blood, liver, and artery wall," Journal of Lipid Research, vol. 50, pp. S156-S161, 2009.

[114] D. F. Hunt, H. Michel, T. A. Dickinson, et al., "Peptides presented to the immune system by the murine class II major histocompatibility complex molecule I-A(d)," Science, vol. 256, no. 5065, pp. 1817-1820, 1992.

[115] B. J. Rider, E. Fraga, Q. Yu, and B. Singh, "Immune responses to self peptides naturally presented by murine class II major histocompatibility complex molecules," Molecular Immunology, vol. 33, no. 7-8, pp. 625-633, 1996.

[116] T. A. Stephens, E. Nikoopour, B. J. Rider, et al., "Dendritic cell differentiation induced by a self-peptide derived from apolipoprotein E," Journal of Immunology, vol. 181, no. 10, pp. 6859-6871, 2008.

[117] J. R. Lynch, W. Tang, H. Wang, et al., "APOE genotype and an ApoE-mimetic peptide modify the systemic and central nervous system inflammatory response," Journal of Biological Chemistry, vol. 278, no. 49, pp. 48529-48533, 2003.

[118] T. Pham, A. Kodvawala, and D. Y. Hui, "The receptor binding domain of apolipoprotein $\mathrm{E}$ is responsible for its antioxidant activity," Biochemistry, vol. 44, no. 20, pp. 7577-7582, 2005.

[119] Y. Zhou, A. Cheshire, L. A. Howell, D. H. Ryan, and R. B. Harris, "Neuroautoantibody immunoreactivity in relation to aging and stress in apolipoprotein E-deficient mice," Brain Research Bulletin, vol. 49, no. 3, pp. 173-179, 1999.

[120] D. J. Grainger, J. Reckless, and E. McKilligin, "Apolipoprotein E modulates clearance of apoptotic bodies in vitro and in vivo, resulting in a systemic proinflammatory state in apolipoprotein E-deficient mice," Journal of Immunology, vol. 173, no. 10, pp. 6366-6375, 2004.

[121] U. K. Misra, C. L. Adlakha, G. Gawdi, M. K. McMillian, S. V. Pizzo, and D. T. Laskowitz, "Apolipoprotein E and mimetic peptide initiate a calcium-dependent signaling response in macrophages," Journal of Leukocyte Biology, vol. 70, no. 4, pp. 677-683, 2001.

[122] J. Ruiz, D. Kouiavskaia, M. Migliorini, et al., "The apoE isoform binding properties of the VLDL receptor reveal marked differences from LRP and the LDL receptor," Journal of Lipid Research, vol. 46, no. 8, pp. 1721-1731, 2005.

[123] A. F. Hahn, "Guillain-Barré syndrome," The Lancet, vol. 352, no. 9128, pp. 635-641, 1998.

[124] K. A. Sheikh, T. W. Ho, I. Nachamkin, et al., "Molecular mimicry in Guillain-Barré syndrome," Annals of the New York Academy of Sciences, vol. 845, pp. 307-321, 1998.

[125] J. Pritchard, R. A. C. Hughes, J. H. Rees, H. J. Willison, and J. A. R. Nicoll, "Apolipoprotein E genotypes and clinical outcome in Guillain-Barré syndrome," Journal of Neurology Neurosurgery and Psychiatry, vol. 74, no. 7, pp. 971-973, 2003.

[126] T. Jin, L. S. Hu, M. Chang, J. Wu, B. Winblad, and J. Zhu, "Proteomic identification of potential protein markers in cerebrospinal fluid of GBS patients," European Journal of Neurology, vol. 14, no. 5, pp. 563-568, 2007.
[127] Y. R. Yang, S. L. Liu, Z. Y. Qin, et al., "Comparative proteomics analysis of cerebrospinal fluid of patients with Guillain-Barré syndrome," Cellular and Molecular Neurobiology, vol. 28, no. 5, pp. 737-744, 2008.

[128] M. F. Linton, R. Gish, S. T. Hubl, et al., "Phenotypes of apolipoprotein B and apolipoprotein E after liver transplantation," Journal of Clinical Investigation, vol. 88, no. 1, pp. 270-281, 1991.

[129] M. Danik, D. Champagne, C. Petit-Turcotte, U. Beffert, and J. Poirier, "Brain lipoprotein metabolism and its relation to neurodegenerative disease," Critical Reviews in Neurobiology, vol. 13, no. 4, pp. 357-407, 1999.

[130] G. K. Harvey, R. Gold, K. V. Toyka, and H. P. Hartung, "Nonneural-specific T lymphocytes can orchestrate inflammatory peripheral neuropathy," Brain, vol. 118, no. 5, pp. 1263-1272, 1995.

[131] J. D. Pollard, K. W. Westland, G. K. Harvey, et al., "Activated $T$ cells of nonneural specificity open the blood-nerve barrier to circulating antibody," Annals of Neurology, vol. 37, no. 4, pp. 467-475, 1995.

[132] S. M. Fullerton, G. A. Shirman, W. J. Strittmatter, and W. D. Matthew, "Impairment of the blood-nerve and blood-brain barriers in apolipoprotein E knockout mice," Experimental Neurology, vol. 169, no. 1, pp. 13-22, 2001.

[133] S. Yu, R. S. Duan, Z. Chen, et al., "Increased susceptibility to experimental autoimmune neuritis after upregulation of the autoreactive $\mathrm{T}$ cell response to peripheral myelin antigen in apolipoprotein E-deficient mice," Journal of Neuropathology \& Experimental Neurology, vol. 63, pp. 120-128, 2004.

[134] J. F. Goodrum, "Cholesterol from degenerating nerve myelin becomes associated with lipoproteins containing apolipoprotein E," Journal of Neurochemistry, vol. 56, no. 6, pp. 20822086, 1991.

[135] H. W. Harris, "Apolipoprotein E: from Alzheimer's to sepsis," Critical Care Medicine, vol. 33, no. 11, pp. 2696-2697, 2005.

[136] B. H. Waksman and R. D. Adams, "Allergic neuritis: an experimental disease of rabbits induced by the injection of peripheral nervous tissue and adjuvants," Journal of Experimental Medicine, vol. 102, pp. 213-236, 1955.

[137] A. Rostami, S. K. Gregorian, M. J. Brown, and D. E. Pleasure, "Induction of severe experimental autoimmune neuritis with a synthetic peptide corresponding to the 5378 amino acid sequence of the myelin P2 protein," Journal of Neuroimmunology, vol. 30, no. 2-3, pp. 145-151, 1990.

[138] L. P. Zou, H. G. Ljunggren, M. Levi, et al., "P0 protein peptide 180-199 together with pertussis toxin induces experimental autoimmune neuritis in resistant C57BL/6 mice," Journal of Neuroscience Research, vol. 62, no. 5, pp. 717-721, 2000.

[139] H. P. Hartung, H. Willison, S. Jung, M. Pette, K. V. Toyka, and G. Giegerich, "Autoimmune responses in peripheral nerve," Springer Seminars in Immunopathology, vol. 18, no. 1, pp. 97123, 1996.

[140] W. Pan and A. J. Kastin, "Changing the chemokine gradient: CINC1 crosses the blood-brain barrier," Journal of Neuroimmunology, vol. 115, pp. 64-70, 2001.

[141] L. P. Zou, S. H. Pelidou, N. Abbas, et al., "Dynamics of production of MIP- $1 \alpha, \mathrm{MCP}-1$ and MIP-2 and potential role of neutralization of these chemokines in the regulation of immune responses during experimental autoimmune neuritis in Lewis rats," Journal of Neuroimmunology, vol. 98, no. 2, pp. 168-175, 1999. 
[142] T. Olsson, "Critical influences of the cytokine orchestration on the outcome of myelin antigen-specific T-cell autoimmunity in experimental autoimmune encephalomyelitis and multiple sclerosis," Immunological Reviews, vol. 144, pp. 245 268, 1995.

[143] S. Romagnani, “The Th1/Th2 paradigm," Immunology Today, vol. 18, no. 6, pp. 263-266, 1997.

[144] J. Zhu, E. Mix, and H. Link, "Cytokine production and the pathogenesis of experimental autoimmune neuritis and Gulllain-Barré syndrome," Journal of Neuroimmunology, vol. 84, no. 1, pp. 40-52, 1998.

[145] T. Fujioka, T. Jimi, B. A. Hilliard, E. S. Ventura, and A. Rostami, "The expression of cytokine mRNA in the cauda equina of Lewis rats with experimental allergic neuritis," Journal of Neuroimmunology, vol. 84, no. 2, pp. 223-229, 1998.

[146] J. Zhu, X. F. Bai, E. Mix, and H. Link, "Cytokine dichotomy in peripheral nervous system influences the outcome of experimental allergic neuritis: dynamics of mRNA expression for IL- $1 \beta$, IL-6, IL-10, IL-12, TNF- $\alpha$, TNF- $\beta$, and cytolysin," Clinical Immunology and Immunopathology, vol. 84, no. 1, pp. 85-94, 1997.

[147] J. Zhu, X. F. Bai, E. Mix, and H. Link, "Experimental allergic neuritis: cytolysin mRNA expression is upregulated in lymph node cells during convalescence," Journal of Neuroimmunology, vol. 78, no. 1-2, pp. 108-116, 1997.

[148] B. Schmidt, G. Stoll, H. P. Hartung, K. Heininger, B. Schafer, and K. V. Toyka, "Macrophages but not Schwann cells express Ia antigen in experimental autoimmune neuritis," Annals of Neurology, vol. 28, no. 1, pp. 70-77, 1990.

[149] S. Jung, I. Huitinga, B. Schmidt, et al., "The role of macrophages in dichlormethylene diphosphonatecontaining liposomes suppresses experimental autoimmune neuritis," Journal of the Neurological Sciences, vol. 119, no. 2, pp. 195-202, 1993.

[150] R. Kiefer, B. C. Kieseier, G. Stoll, and H. P. Hartung, "The role of macrophages in immune-mediated damage to the peripheral nervous system," Progress in Neurobiology, vol. 64, no. 2, pp. 109-127, 2001.

[151] R. Gold, J. J. Archelos, and H. P. Hartung, "Mechanisms of immune regulation in the peripheral nervous system," Brain Pathology, vol. 9, no. 2, pp. 343-360, 1999.

[152] G. Conti, A. Rostami, E. Scarpini, et al., "Inducible nitric oxide synthase (iNOS) in immune-mediated demyelination and Wallerian degeneration of the rat peripheral nervous system," Experimental Neurology, vol. 187, no. 2, pp. 350-358, 2004.

[153] G. Meyer zu Hörste, W. Hu, H. P. Hartung, H. C. Lehmann, and B. C. Kieseier, "The immunocompetence of Schwann cells," Muscle \& Nerve, vol. 37, pp. 3-13, 2008.

[154] C. L. Koski, "Mechanisms of Schwann cell damage in inflammatory neuropathy," Journal of Infectious Diseases, vol. 176, supplement 2, pp. S169-S172, 1997.

[155] R. S. Duan, T. Jin, X. Yang, E. Mix, A. Adem, and J. Zhu, "Apolipoprotein E deficiency enhances the antigenpresenting capacity of Schwann cells," Glia, vol. 55, no. 7, pp. 772-776, 2007.

[156] J. K. Boyles, C. D. Zoellner, L. J. Anderson, et al., "A role for apolipoprotein E, apolipoprotein A-I, and low density lipoprotein receptors in cholesterol transport during regeneration and remyelination of the rat sciatic nerve," Journal of Clinical Investigation, vol. 83, no. 3, pp. 1015-1031, 1989.
[157] J. F. Goodrum, J. E. Weaver, N. D. Goines, and T. W. Bouldin, "Fatty acids from degenerating myelin lipids are conserved and reutilized for myelin synthesis during regeneration in peripheral nerve," Journal of Neurochemistry, vol. 65, no. 4, pp. 1752-1759, 1995.

[158] J. Poirier, A. Baccichet, D. Dea, and S. Gauthier, "Cholesterol synthesis and lipoprotein reuptake during synaptic remodelling in hippocampus in adult rats," Neuroscience, vol. 55, no. 1, pp. 81-90, 1993.

[159] B. Popko, J. F. Goodrum, T. W. Bouldin, S. H. Zhang, and N. Maeda, "Nerve regeneration occurs in the absence of apolipoprotein E in mice," Journal of Neurochemistry, vol. 60, no. 3, pp. 1155-1158, 1993.

[160] C. Ramassamy, P. Krzywkowski, D. Averill, et al., "Impact of apoE deficiency on oxidative insults and antioxidant levels in the brain," Molecular Brain Research, vol. 86, no. 1-2, pp. 7683, 2001.

[161] D. R. Riddell, H. Zhou, K. Atchison, et al., "Impact of Apolipoprotein E (ApoE) polymorphism on brain ApoE levels," Journal of Neuroscience, vol. 28, no. 45, pp. 1144511453, 2008.

[162] L. M. Dong and K. H. Weisgraber, "Human apolipoprotein E4 domain interaction. Arginine 61 and glutamic acid 255 interact to direct the preference for very low density lipoproteins," Journal of Biological Chemistry, vol. 271, no. 32, pp. 19053-19057, 1996.

[163] K. H. Weisgraber and R. W. Mahley, "Human apolipoprotein E: the Alzheimer's disease connection," FASEB Journal, vol. 10, no. 13, pp. 1485-1494, 1996.

[164] R. E. Gregg, L. A. Zech, E. J. Schaefer, D. Stark, D. Wilson, and H. B. Brewer Jr., "Abnormal in vivo metabolism of apolipoprotein E4 in humans," Journal of Clinical Investigation, vol. 78, no. 3, pp. 815-821, 1986.

[165] A. Steinmetz, C. Jakobs, S. Motzny, and H. Kaffarnik, "Differential distribution of apolipoprotein E isoforms in human plasma lipoproteins," Arteriosclerosis, vol. 9, no. 3, pp. 405-411, 1989.

[166] K. H. Weisgraber, "Apolipoprotein E distribution among human plasma lipoproteins: role of the cysteine-arginine interchange at residue 112," Journal of Lipid Research, vol. 31, no. 8, pp. 1503-1511, 1990.

[167] R. G. Struble, E. R. Rosario, M. L. Kircher, et al., "Regionally specific modulation of brain apolipoprotein $\mathrm{E}$ in the mouse during the estrous cycle and by exogenous $17 \beta$ estradiol," Experimental Neurology, vol. 183, no. 2, pp. 638-644, 2003.

[168] J. Levin-Allerhand, B. S. McEwen, C. E. Lominska, D. B. Lubahn, K. S. Korach, and J. D. Smith, "Brain region-specific up-regulation of mouse apolipoprotein E by pharmacological estrogen treatments," Journal of Neurochemistry, vol. 79, no. 4, pp. 796-803, 2001.

[169] I. Rozovsky, S. Hoving, C. P. Anderson, J. O’Callaghan, and C. E. Finch, "Equine estrogens induce apolipoprotein E and glial fibrillary acidic protein in mixed glial cultures," Neuroscience Letters, vol. 323, no. 3, pp. 191-194, 2002.

[170] T. L. Innerarity, R. E. Pitas, and R. W. Mahley, "Binding of arginine-rich (E) apoprotein after recombination with phospholipid vesicles to the low density lipoprotein receptors of fibroblasts," The Journal of Biological Chemistry, vol. 254, pp. 4186-4190, 1979.

[171] M. Narita, D. M. Holtzman, A. M. Fagan, et al., "Cellular catabolism of lipid poor apolipoprotein E via cell surface LDL 
receptor-related protein," Journal of Biochemistry, vol. 132, no. 5, pp. 743-749, 2002.

[172] J. I. Osuga, M. Yonemoto, N. Yamada, et al., "Cholesterol lowering in low density lipoprotein receptor knockout mice overexpressing apolipoprotein E," Journal of Clinical Investigation, vol. 102, no. 2, pp. 386-394, 1998. 


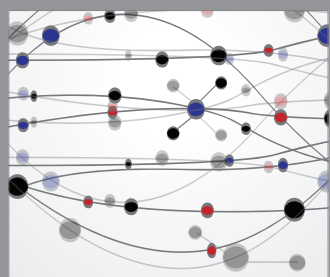

The Scientific World Journal
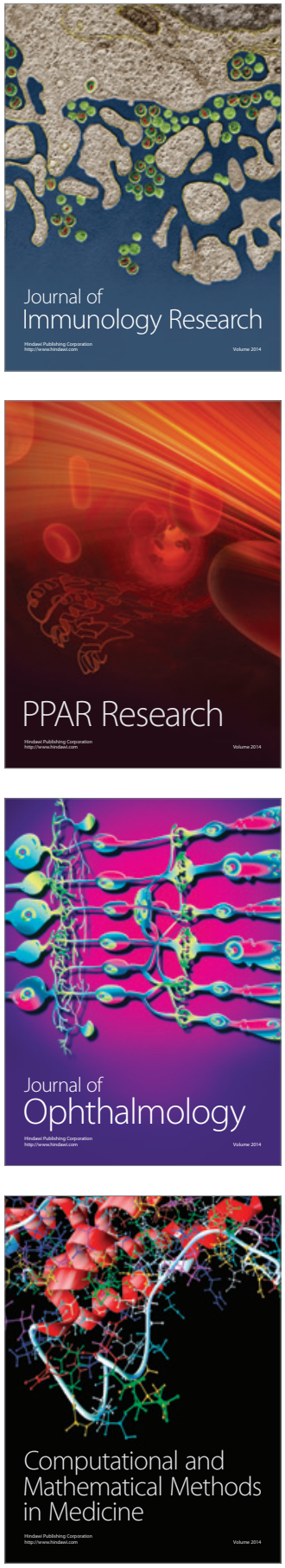

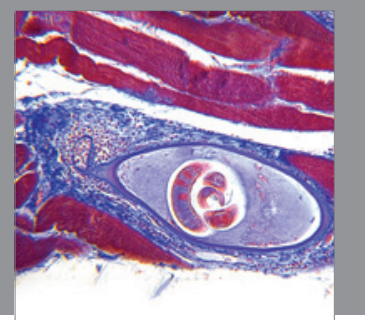

Gastroenterology

Research and Practice
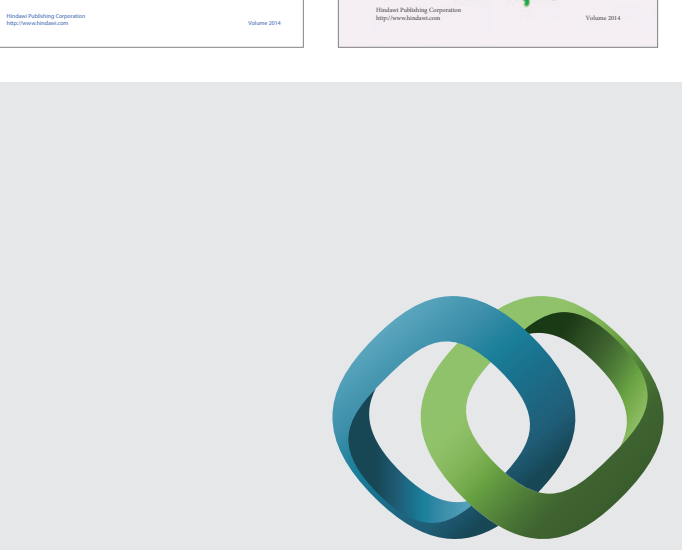

\section{Hindawi}

Submit your manuscripts at

http://www.hindawi.com
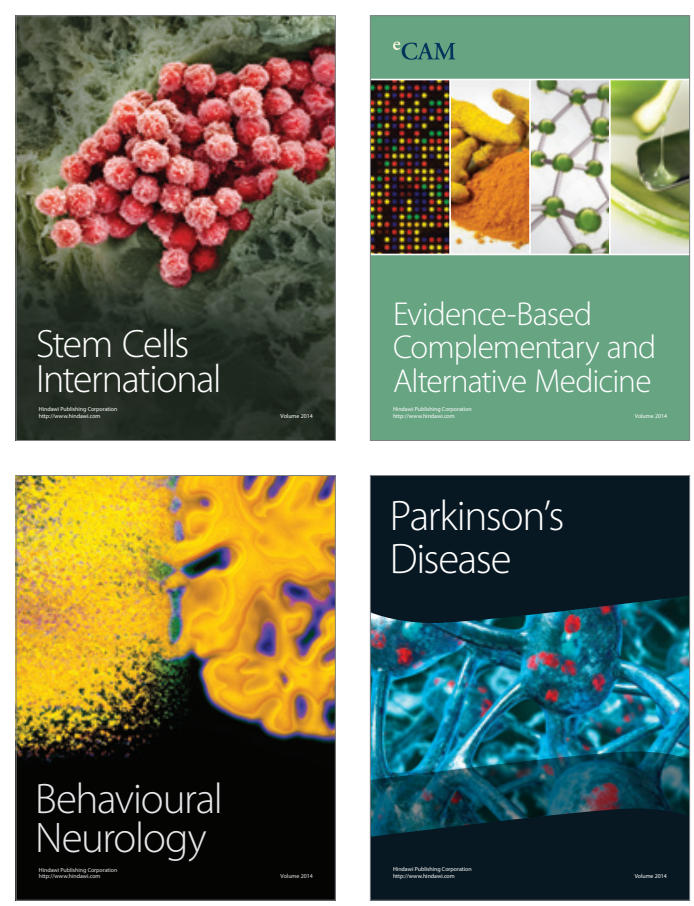

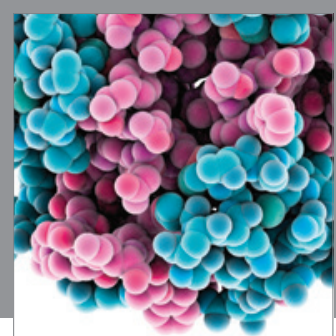

Journal of
Diabetes Research

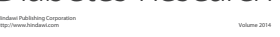

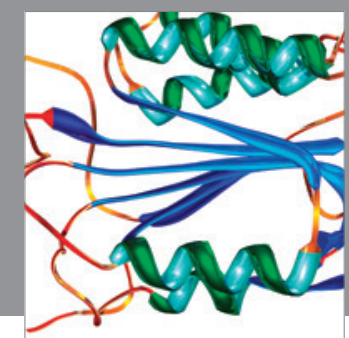

Disease Markers
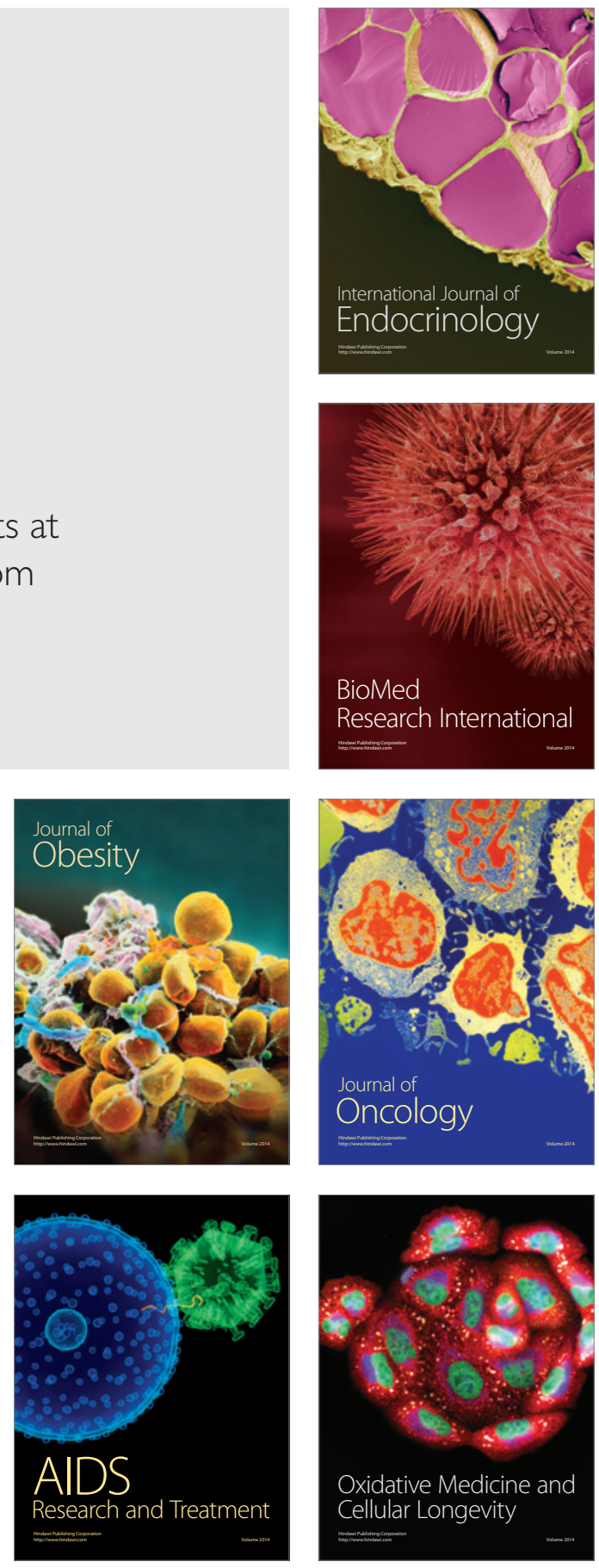